\title{
CORRECTION
}

Open Access

\section{Correction: Hepatitis B virus infection and replication in human bone marrow mesenchymal stem cells}

Ruiping Ma ${ }^{1}$, Quantai Xing ${ }^{1}$, Lihua Shao ${ }^{2}$, Dakun Wang ${ }^{3}$, Qingzhi Hao ${ }^{4}$, Xia Li ${ }^{5}$, Lintao Sai ${ }^{1}$ and Lixian Ma ${ }^{1 *}$

\section{Correction}

After publication of this work [1], we noted that D of Figure 1 was incorrect. Now the correct figure has been provided with this correction.
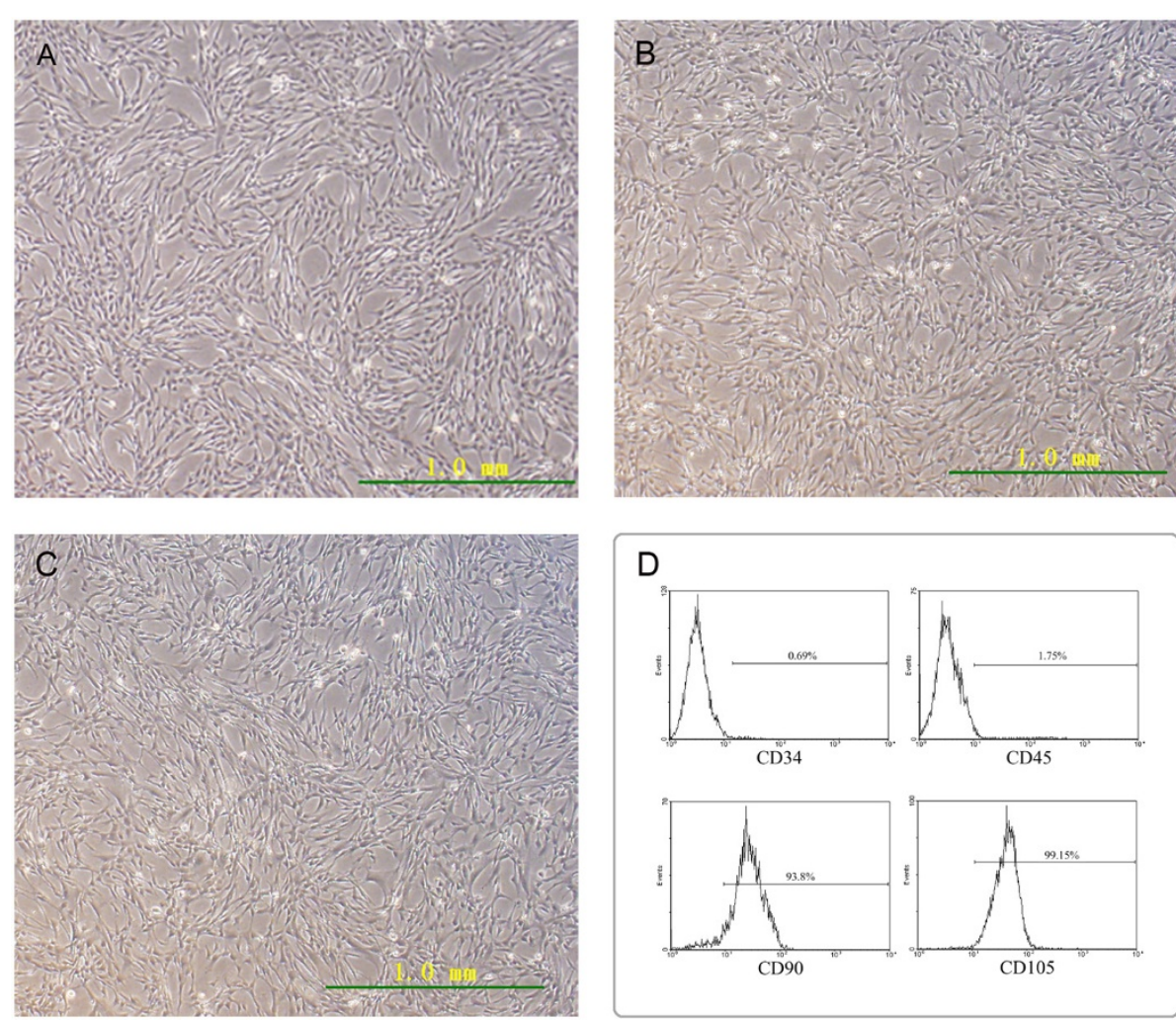

Figure 1 Characterization of human BMSCs. (A) Morphology of the third generation of human BMSCs under light microscope. (B) Morphology of the eighth generation of infected human BMSCs under light microscope. (C) Morphology of the eighth generation of uninfected human BMSCs under light microscope. (D) Analysis by flow cytometry showed that human BMSCs at passage 5 were negative for the expression of CD34 and CD45, but positive for the expression of CD90 and CD105.

\section{* Correspondence: shandongqilu@gmail.com}

'Department of Infectious Diseases, Qilu Hospital, Shandong University,

Wenhua Xi Road 107, Jinan 250012, Shandong Province, China

Full list of author information is available at the end of the article 


\section{Author details}

'Department of Infectious Diseases, Qilu Hospital, Shandong University, Wenhua Xi Road 107, Jinan 250012, Shandong Province, China. ${ }^{2}$ Department of Laboratory Sciences, School of Public Health, Shandong University, Wenhua Xi Road 107, Jinan 250012, Shandong Province, China. ${ }^{3}$ Cryo Medicine Laboratory, Qilu Hospital, Shandong University, Wenhua Xi Road 107, Jinan 250012, Shandong Province, China. ${ }^{4}$ Department of Peripheral Vascular, Affiliated Hospital of Shandong University of Traditional Chinese Medicine, Wenhua Xi Road 42, Jinan 250011, Shandong Province, China. ${ }^{5}$ Laboratory for Tumor Immunity and Traditional Chinese Drug Immunity, Institute of Basic Medicine, Shandong Academy of Medical Science, Jingshi Road 89, Jinan 250062, Shandong Province, China.

Received: 20 March 2012 Accepted: 19 April 2012

Published: 4 May 2012

\section{Reference}

1. Ma R, Xing Q, Shao L, Wang D, Hao Q, Li X, Sai L, Ma L: Hepatitis B virus infection and replication in human bone marrow mesenchymal stem cells. Virol J 2011, 8:486.

doi:10.1186/1743-422X-9-87

Cite this article as: Ma et al:: Correction: Hepatitis B virus infection and replication in human bone marrow mesenchymal stem cells. Virology Journal 2012 9:87.

\section{Submit your next manuscript to BioMed Central and take full advantage of:}

- Convenient online submission

- Thorough peer review

- No space constraints or color figure charges

- Immediate publication on acceptance

- Inclusion in PubMed, CAS, Scopus and Google Scholar

- Research which is freely available for redistribution 